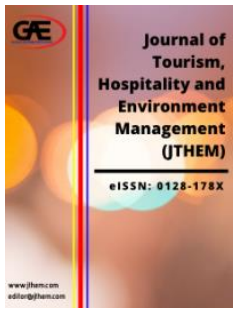

\author{
JOURNAL OF TOURISM, \\ HOSPITALITY AND \\ ENVIRONMENT MANAGEMENT \\ (JTHEM) \\ www.jthem.com
}

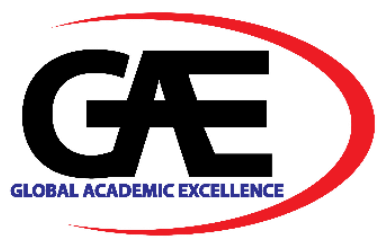

\title{
SPATIAL PATTERN OF BOKO HARAM ATTACKS AND FATALITIES AND TOURISM BUSINESSES ACROSS STATES IN THE NORTH EASTERN NIGERIA
}

\author{
Inyang, Oduduabasi ${ }^{1 *}$, Olanrewaju Lawal ${ }^{2}$ \\ 1 Department of Hospitality and Tourism Management, Federal University Wukari, Taraba State, Nigeria \\ Email: inyangebong@fuwukari.edu.ng \\ 2 Department of Geography and Environmental Management, University of Port Harcourt, Nigeria. \\ Email: olanrewaju.lawal@uniport.edu.ng \\ Corresponding Author
}

\section{Article Info:}

Article history:

Received date: 02.11.2020

Revised date: 22.11 .2020

Accepted date: 03.12.2020

Published date: 10.12 .2020

\section{To cite this document:}

Oduduabasi, I., \& Lawal, O. (2020). Spatial Pattern Of Boko Haram Attacks And Fatalities And Tourism Businesses Across States In The North Eastern Nigeria. Journal of Tourism, Hospitality and Environment Management, 5 (21), 184-199.

DOI: 10.35631/JTHEM.5210011.

This work is licensed under $\mathrm{CC}$ BY 4.0

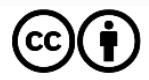

Abstract:

This study was on the spatial exploration of Boko Haram terrorist attacks and its influence on components of tourism businesses (hotels) in Northeastern Nigeria. Secondary data on location, nature, date, and number of fatalities from the Boko Haram attack were sourced from Armed Conflict Location \& Event Data (ACLED). Data on the location of hotels were sourced from the field with the use of the Geographic Positioning System (GPS). A total of 558 hotels were selected in a one-stage cluster sampling technique. The study adopts a longitudinal research design where centrographic analysis was carried out to describe the spatial distribution of events. Results of the study revealed that Boko Haram attacks were more coordinated rather than a random occurrence with most of the attacks concentrated in Borno State. Furthermore, Boko Haram did not directly target tourism businesses though some of the hotels fell within a $1.5 \mathrm{~km}$ radius of the attacks. The study, therefore, recommends for an intense media promotion of the areas and States not majorly affected by the crisis, rebuilding of areas and States recovered from the group, provisions of more resilient security apparatus, and general development of social, educational, and economic infrastructures to help revamp not only the tourism sector of the area but its general socioeconomic activities.

Keywords:

Tourism Businesses, Terrorist Attacks, Boko Haram, North Eastern Nigeria 


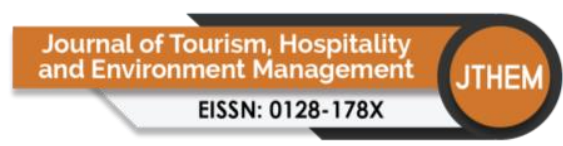

Volume 5 Issue 21 (December 2020) PP. 184-199

\section{Introduction}

DOI 10/35631/JTHEM.5210011

The past decade has witnessed an onslaught of terrorist activities championing mainly by the Boko Haram terrorist group which has largely been domesticated in the north eastern part of Nigeria made up of Borno, Yobe, Adamawa, Bauchi, Taraba and Gombe state. Many research works (Benashvili, 2016; Bird, 2008; Folarin \& Adogheje, 2017; Adeboje, 2014) has been carried out on terrorism but most of these researches did not only failed to captured or analyzed the effects of terrorism on tourism in Nigeria but also failed to looked at the effects terror activities had on the tourism subsector of the Northeast region of the country in particular bearing in mind the localization of terrorism activities around this region. It is also interesting to note that most of these studies concentrated on the direct effects of terrorism which mostly looked at the physical damage to properties and number of casualties as a result of terror attacks while failing to consider the long term effects these attacks has on the economy in general and tourism subsector in particular. For example, Benashvili (2016) looked at the direct economic effect of Boko Haram attacks in Nigeria and found that the direct economic impact is considerably smaller than the size of the economy. Ajogbeje and Folarin (2017) looked at the effect of terrorism on economy of Nigeria where they found a negative response of economic variables to terrorist incidents over the long haul. This study was not specific on the north eastern part of Nigeria and did not looked at specific tourism variables but focused on foreign direct investment (FDI) on the nation's economy generally. Another work by Adebayo (2014) looked at the implications of 'Boko Haram' Terrorism on National Development in Nigeria. The study maintained that the Boko Haram activities have significantly affected the general business environment of the country and has scared investors away. Again, this study did not consider how the terrorist activities affect tourism in particular. Other authors like Omede (2013) worked on terrorism and insecurity in Nigeria and found direct link between terrorism and low FDI. Bosede (2015) worked on terrorism in Northern Nigeria but concentrated on how terrorism is a threat to food security in Maiduguri. Direct effects arising from terrorism measures things like loss of life, costs associated with injuries, damaged property and infrastructure, and other business and trade losses (Shah and Faiz, 2015), these effects occur shortly after the attack. On the other hand, indirect effect of terrorism on tourism takes time to manifest according to Brück and Wickström (2004). According to these authors, indirect effects occur in the long run and it is rather difficult to measure due to various reasons such as measurement, data collection and estimation difficulties. Indirect effects are heavier and more severe than direct effect (Brück and Wickström, 2004). Indirect effects are therefore related to tourism economy, fiscal and financial issues. In this respect, indirect effects of terrorism focus on factors such as tourism growth, tourism financial markets and investment, FDI to the tourism sector, unemployment and financial factors such as public expenditures and government borrowing costs. As has been said before, there is a total lack of research on the effects of terrorism on tourism in north eastern region of Nigerian which therefore provides the gap the current research aims to fill.

\section{Literature Review}

\section{Tourism and Hospitality Contribution to the Economy}

Researchers like Page and Connel, (2006), Sonmez and Graefe, (1998), Baker, (2014) has established in their works that terrorism activities produced one of the most skewed relationships with tourism and can therefore be judged as tourism number one enemy. United Nation World Tourism Organization (UNWTO, 2005) described tourism as the jewel of development for many developing worlds. This is because tourism is widely regarded as one 


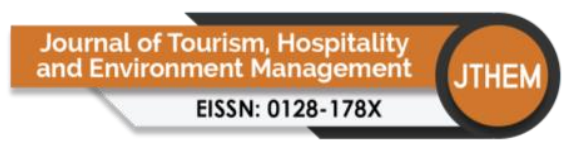

Volume 5 Issue 21 (December 2020) PP. 184-199 DOI 10/35631/JTHEM.5210011

of the largest and fastest growing economic sector in the world. Since the 1980s, tourism has been one of the leading growth sectors in the global economy. Data from UNWTO (2010) revealed that from 1950 to 2010; international tourist arrivals grew from 25 million to 940 million. The sector has seen significant growth in revenue and employment as well as the development of new and fledgling markets. It contributes significantly to national GDPs and is a top employer in the economies of many nations. Tourism is labor intensive service which means it employs a lot of people in developing world where jobs are still limited. It is also a security sensitive activity which means that any hints of threat and danger to tourists can damage it (UNWTO, 2010).

Tourism and Hospitality industry has become one of the fastest growing economic sector in the world according to UNWTO (2005), but also one of the most sensitive to crisis. Unexpected and uncalculated threats like terrorism is a major concern in this industry and can result in significant drops in tourist arrivals and negatively impacting on the general tourism industry of any destination. Undeniable, terrorism activities have been on the rise in the last decade in Nigeria, largely due to the insurgency activities of Boko-Haram, herdsmen and farmers clashes. Before the advent and upscale of terrorist activities mainly by Boko Haram, Morgan (2015) argued that there were terror acts in Nigeria but of lesser consequence and gravity and includes acts like communal/tribal wars, sabotage, armed robbery, stealing, kidnapping, among others. The main purpose and intention of the perpetuators of these acts was to gained material benefits with minimal loss of life (Morgan, 2015). Nigeria tourism and Hospitality sector contribute more than $7.5 \%$ to the country GDP and employed about 5.1\% (UNWTO, 2017), making it one of the most important economic and development sectors for the country. However, the violent campaign by Boko Haram in the past decade may have significant effects on the tourism subsector which could contribute to diminishing international tourists' arrivals and reductions in FDI for the country. Nigeria has long endured travel advisories by other governments due to its high-risk security situation. One of such was when in 2010, the US Department of State warned US citizens against traveling to Nigeria citing limited facilities for tourists, existence of violent crimes carried out by ordinary citizens and gangs in military uniforms, kidnappings, and dangerous public transport (USDS, 2010). By 2011, the US Mission in Nigeria advised its citizens to keep off some of the biggest hotels in Abuja including Transcorp Hilton, Sheraton and Nicon Luxury due to imminent threat of Boko Haram attacks. Similarly, the UK government has a travel advisory on Nigeria which could also have negative effects on the country tourism \& hospitality industry. Based on the following discussion, the current study aimed to examine the trend and characteristic (number, age, rooms, class) of tourism businesses (hotels) in the study area and analysing the spatial pattern and distribution of Boko Haram attacks and fatalities across the states in the study area as well as determine spatial location of hotels in relation to spatial distribution of Boko Haram attacks.

\section{Materials and Method}

Primary data including characteristic and coordinates of hotels was collected using specially designed data collection form and GPS. Secondary data for the study includes Boko Haram attacks, date of attacks, nature of attacks and number of fatalities was sourced from ACLED an organization that published data on violent attacks across the globe. The study population comprises of all tourism businesses operating in the area. A list of registered hotels was sourced from each of the State's tourism development board, which revealed that there are a total of 1008 registered hotels spread across the six States of the study area. The six states were subdivided into three clusters of urban, semi-urban and rural areas. The urban and semi-urban 
areas with a total number of 558 registered hotels were selected in one stage cluster sample. Point pattern analysis was performed and a GIS map display as the output.

\section{Results}

\section{Spatial Distribution of Attacks and Fatalities}

The Spatial Distribution of Attacks and Fatalities as displayed in Figure 1 revealed that in 2009, Borno recorded the highest number of attacks $(75 \%)$, with no fatality. This was followed by Bauchi State, which recorded $25 \%$ of attacks but no record of fatality just as Borno. The other four States including Taraba, Yobe, Adamawa and Gombe had no recorded cases of attacks or fatalities in the year.

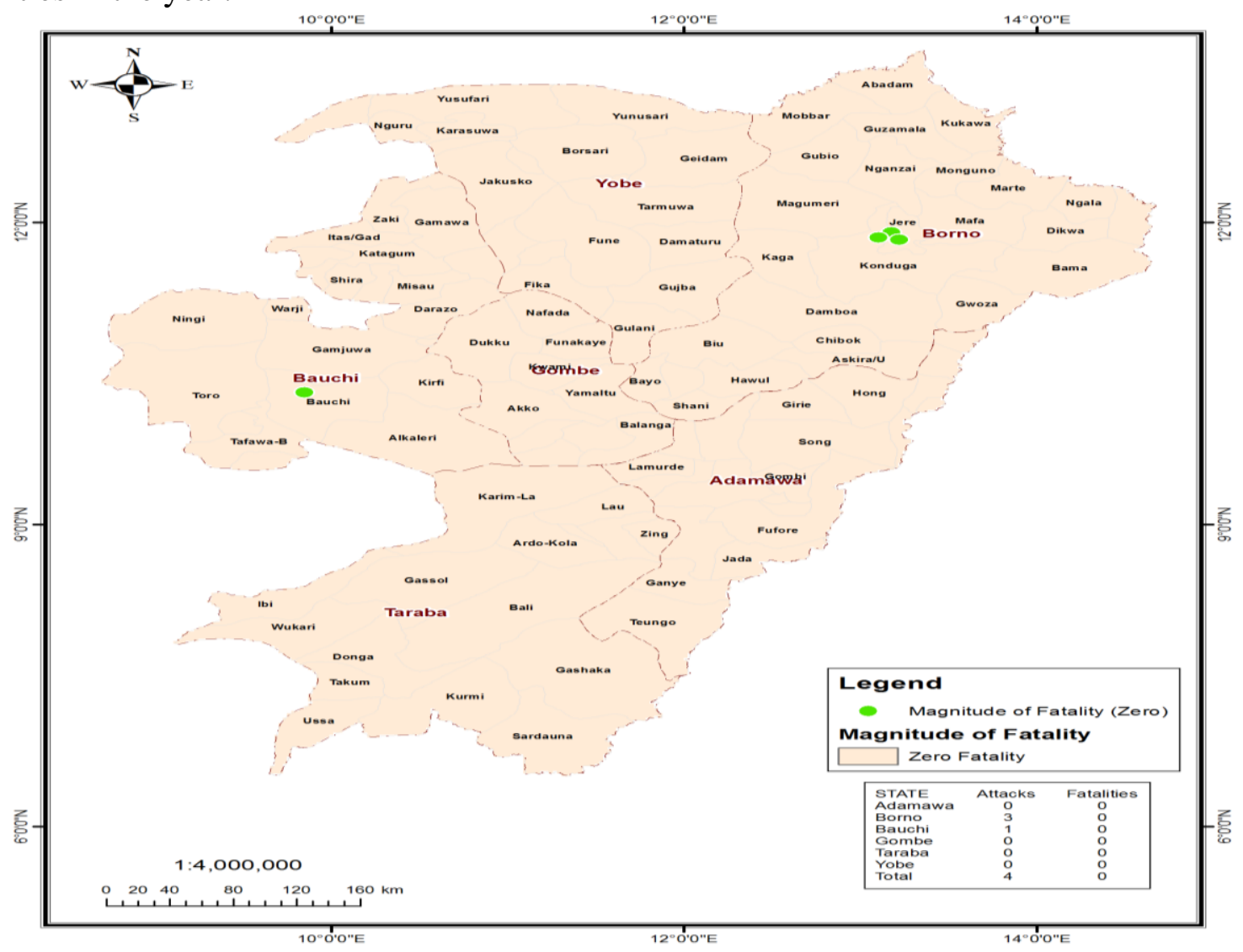

Figure 1: Spatial Distribution of Boko Haram Attacks and Fatalities in 2009 Source: Compiled by Author Based on Data from ACLED, 2019

There was a sharp increase in the number of attacks and magnitude of fatalities from the group in 2010 compared to 2009 (Figure 2). In this year, Borno was the State with the highest percentage of attacks (80\%) and highest percentage of fatalities (82\%); Bauchi recorded the second highest number of attacks $(10 \%)$ and fatalities $(11 \%)$, while Yobe, the third State to be affected in the year recorded the same number $(10 \%)$ of attacks like Bauchi but with a lesser fatalities (7\%). These records revealed an addition of Yobe in the number of States affected by attacks from the group, bringing the number of States directly affected by attacks to three from the previous two in 2009. The other States, including Taraba, Adamawa and Gombe did not record any incident of attack or fatality in the year. 


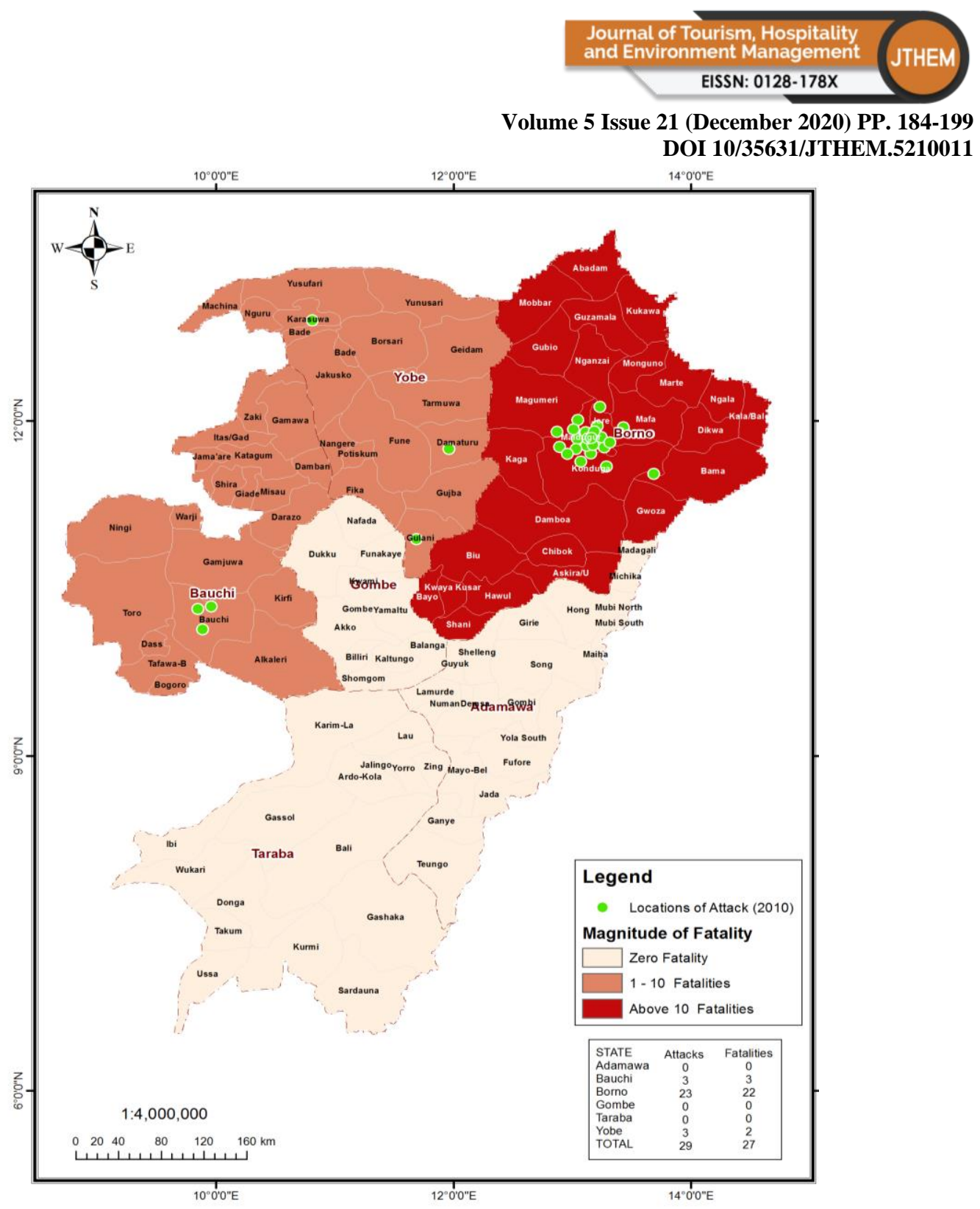

Figure 2: Spatial Distribution of Boko Haram Attacks and Fatalities in 2010

Source: Compiled by Author Based on Data from ACLED, 2019

By 2011, the group has succeeded in spreading their violent attacks across each of the states in the study area except Taraba. The year saw an increased in the number of attacks and number of states directly affected by attacks to 5 as shown in figure 3. During this year, Borno recorded still the highest percent of attacks (82\%), as well fatalities (48\%). Bauchi and Yobe both record the same number of number of attacks $(7 \%)$ but with different outcome of fatalities. In terms of fatalities, Yobe recorded the second highest (34\%), followed by Bauchi (14\%). Adamawa State recorded a lower percentage of attacks (2\%) but with a higher record of fatalities $(5 \%)$. The State with the lowest record of attacks and fatalities was Gombe (1\%) for the year. There was no record of attack or fatality in Taraba State for the year 2011. 


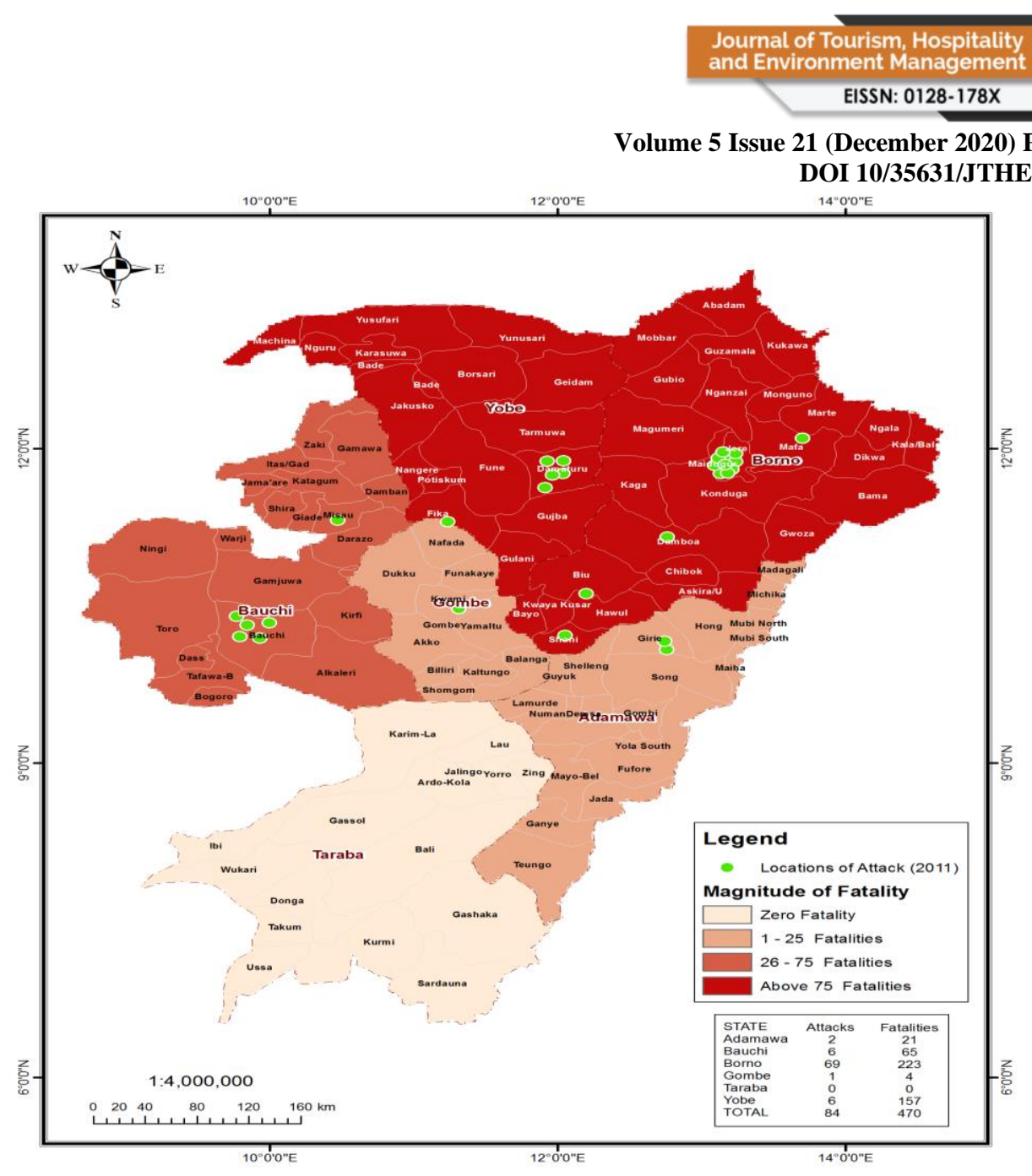

Figure 3: Spatial Distribution of Boko Haram Attacks and Fatalities in 2011

Source: Compiled by Author Based on Data from ACLED, 2019

By 2012, the group had achieved a full coverage of all the states in the study area with more damning records of attacks and fatalities as presented in figure 4. Each of the States had recorded attacks and fatalities in this year. Borno once again had the highest record of attacks $(59 \%)$ and fatalities (53\%). Yobe recorded the second highest number of attacks (19\%), and fatalities (19\%). Bauch recorded the third highest number of attacks $(9 \%)$ but with lower number of fatalities (19\%). Adamawa came in as the fourth highest in terms of attacks $(6 \%)$ but with a higher percentage of fatalities (19\%) compare to Bauchi State. Gombe and Taraba States had a lower number of attacks $(4 \%)$ but a different percentage of fatalities, with Taraba recording a higher fatality (3\%) compare with Gombe (1\%). 


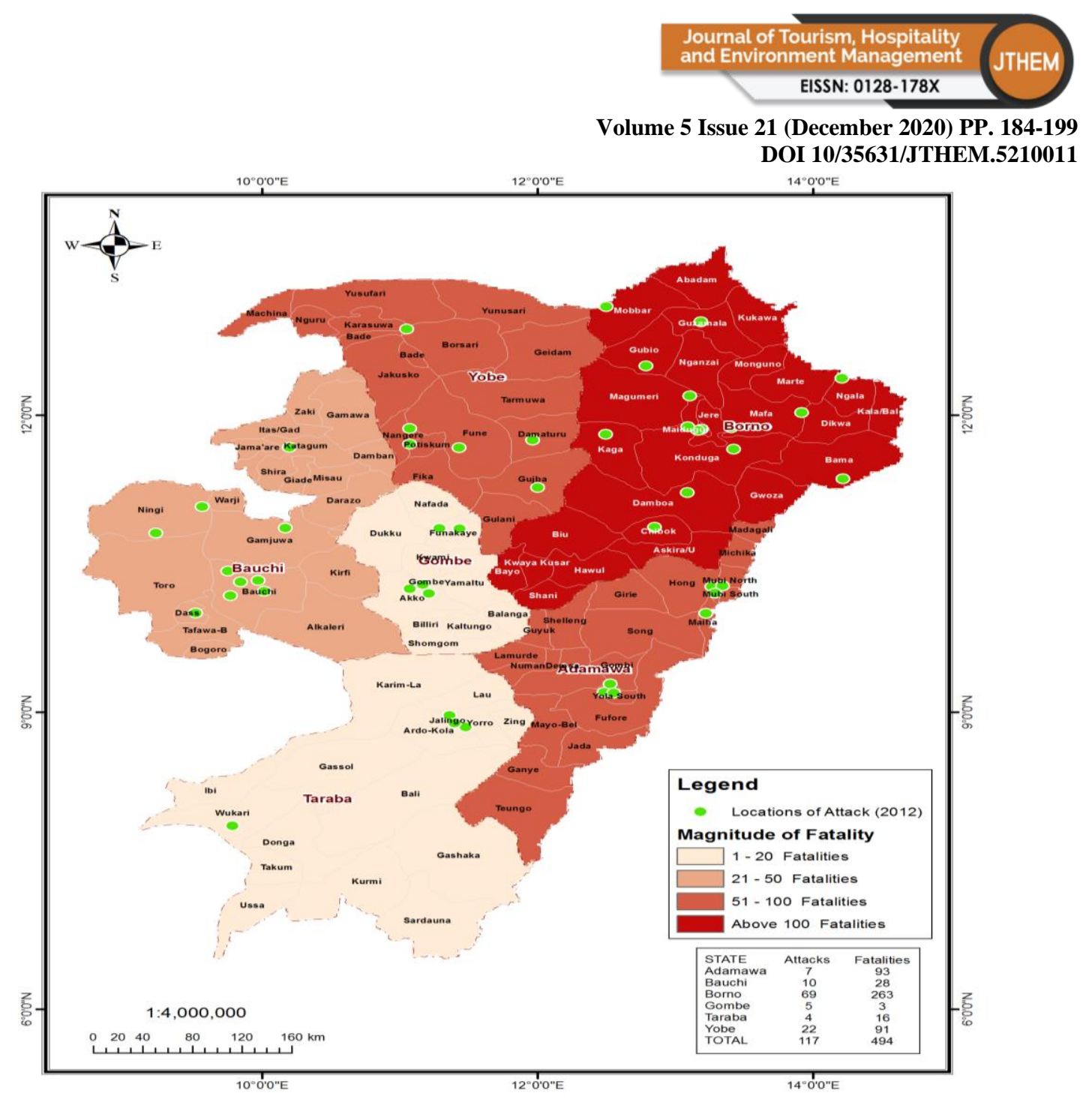

Figure 4: Spatial Distribution of Boko Haram Attacks and Fatalities in 2012 Source: Compiled by Author Based on Data from ACLED, 2019

In 2013, the group has become so wild that they recorded some of the highest number of attacks and heaviest fatalities in their history of operation as represented in Figure 5. The year saw Borno still with the highest record of attacks (81\%) and fatalities (79\%). Yobe State has the second highest number of attacks $(12 \%)$ and fatalities (19\%). Adamawa came as the third highest in terms of attacks (3\%) but with a lower percentage of fatalities (1\%). Gombe recorded the fourth highest attacks $(2 \%)$ and fatalities $(0.1 \%)$. While Taraba and Bauchi States recorded the least number of attacks $(1 \%)$, and fatalities $(0.3 \%)$, respectively for the year. 


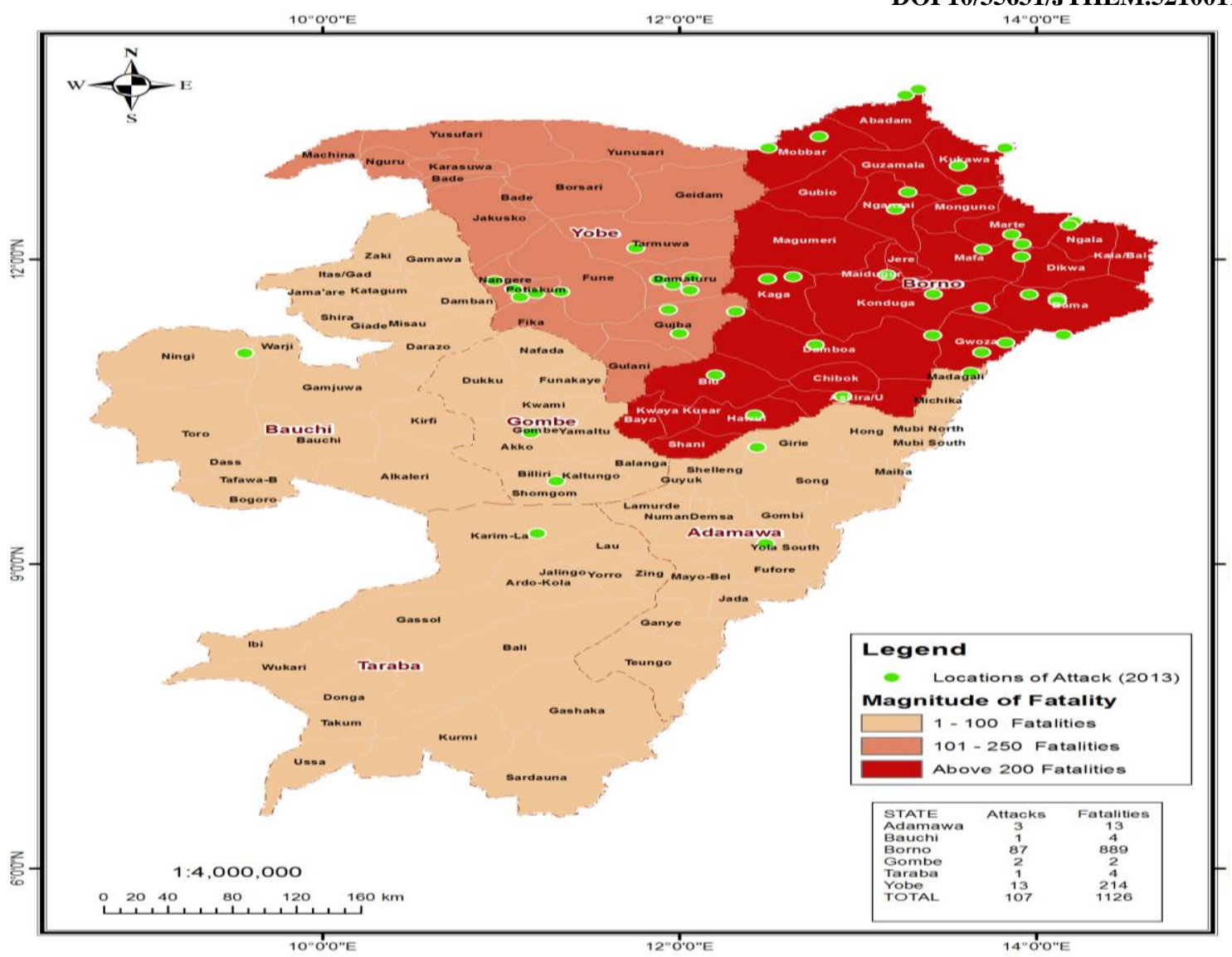

Figure 5: Spatial Distribution of Boko Haram Attacks and Fatalities in 2013

Source: Compiled by Author Based on Data from ACLED, 2019

The year 2014 was another year that recorded some of the highest number of Boko Haram attacks as well as fatalities. In figure 6 , the highest number of attacks $(63 \%)$ and fatalities $(53 \%)$ still came from Borno. The second higest record of attacks (27\%) and fatalities (38\%) went to Adamawa this time around. This was followed by Yobe as the third highest record of attacks $(12 \%)$ and fatalities (8\%). While Bauchi recorded the fourth highest number of attacks $(6 \%)$ but with a lesser percentage of fatalities $(0.3 \%)$, compared to Taraba State which recorded lesser percentage of attacks $(2 \%)$ but a higher percentage of fatalities (2\%) compared Bauchi State. Gombe State had no record of attacks or fatalities in the year. 


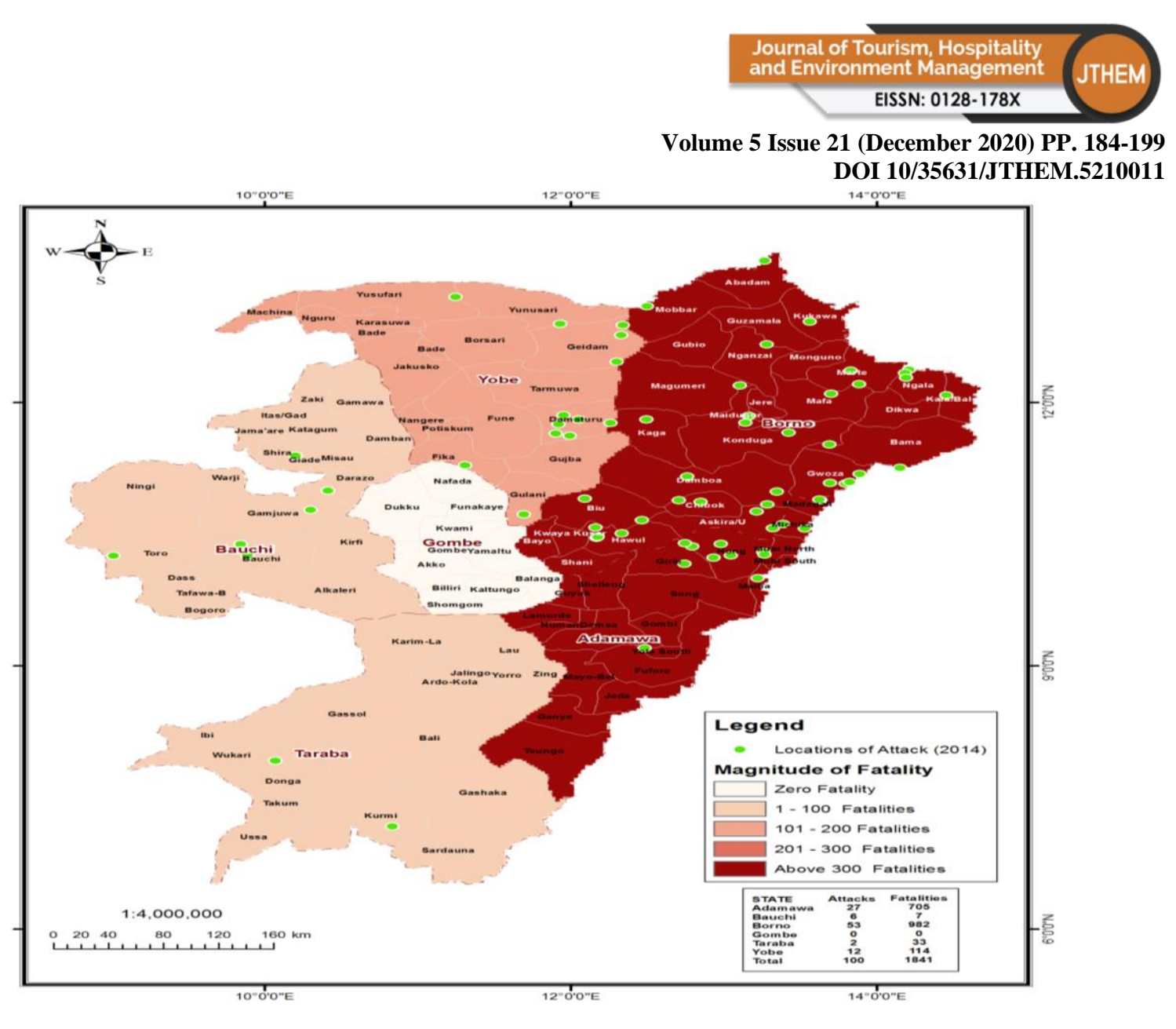

Figure 6: Spatial Distribution of Boko Haram Attacks and Fatalities in 2014 Source: Compiled by Author Based on Data from ACLED, 2019

The year 2015 has the highest fatalities since the group started operation and has not been overtaking by any other year so far as represented in Figure 7. Though Borno recorded lower cases of attacks of (53\%) compared to previous two years, the number of fatalities was higher $(75 \%)$ and stood as the highest so far. Adamawa was the State with the second highest record of attacks (14\%) and fatalities (13\%). This was followed by Yobe, with the third highest record of attacks $(11 \%)$ but with a lower percentage of fatalities $(1 \%)$, compared to Gombe with a lower percentage of attacks (3\%) and the same percent of fatalities as Yobe (1\%). Bauchi State also recorded the same percentage of attacks $(3 \%)$ as Gombe, but with lower fatalities $(0.1 \%)$. While Taraba State had a record of no attacks and fatalities in the year. 


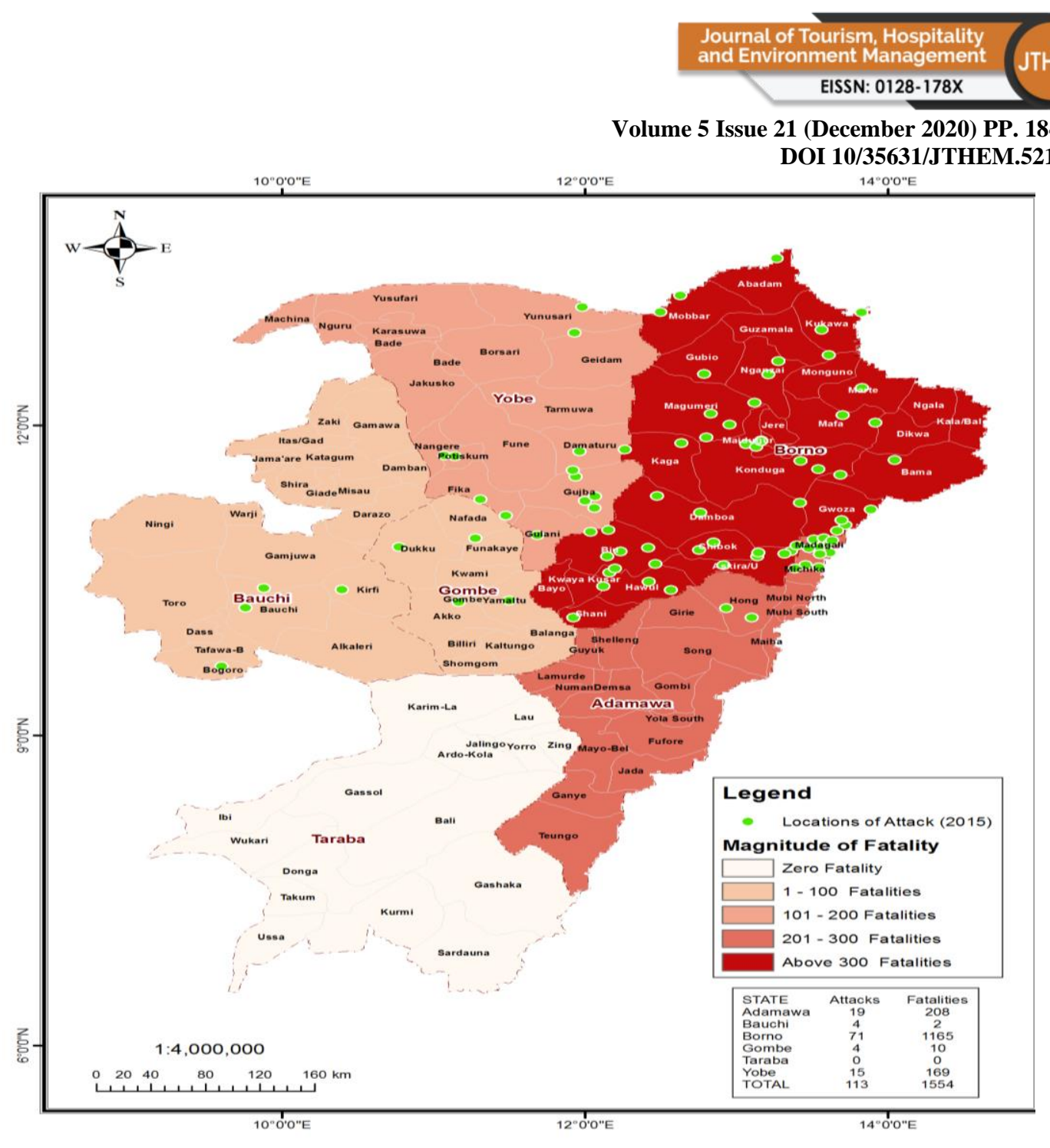

Figure 7: Spatial Distribution of Boko Haram Attacks and Fatalities in 2015 Source: Compiled by Author Based on Data from ACLED, 2019

The year 2016 recorded a first-time reduction in the number of States that were covered by the group since 2010 as shown in Figure 8. Three States including Bauch, Gombe and Taraba did not record any case of attacks in the year. For the first time also Borno recorded lower cases of attacks but still the State with the highest percentage of attacks $(83 \%)$ and fatalities $(86 \%)$. Adamawa and Yobe State both recorded the same number of attacks (9\%) but with different percentage of fatalities. Adamawa State had the second highest fatalities (10\%) and Yobe recorded the least percentage of fatalities $(4 \%)$ in the year. 


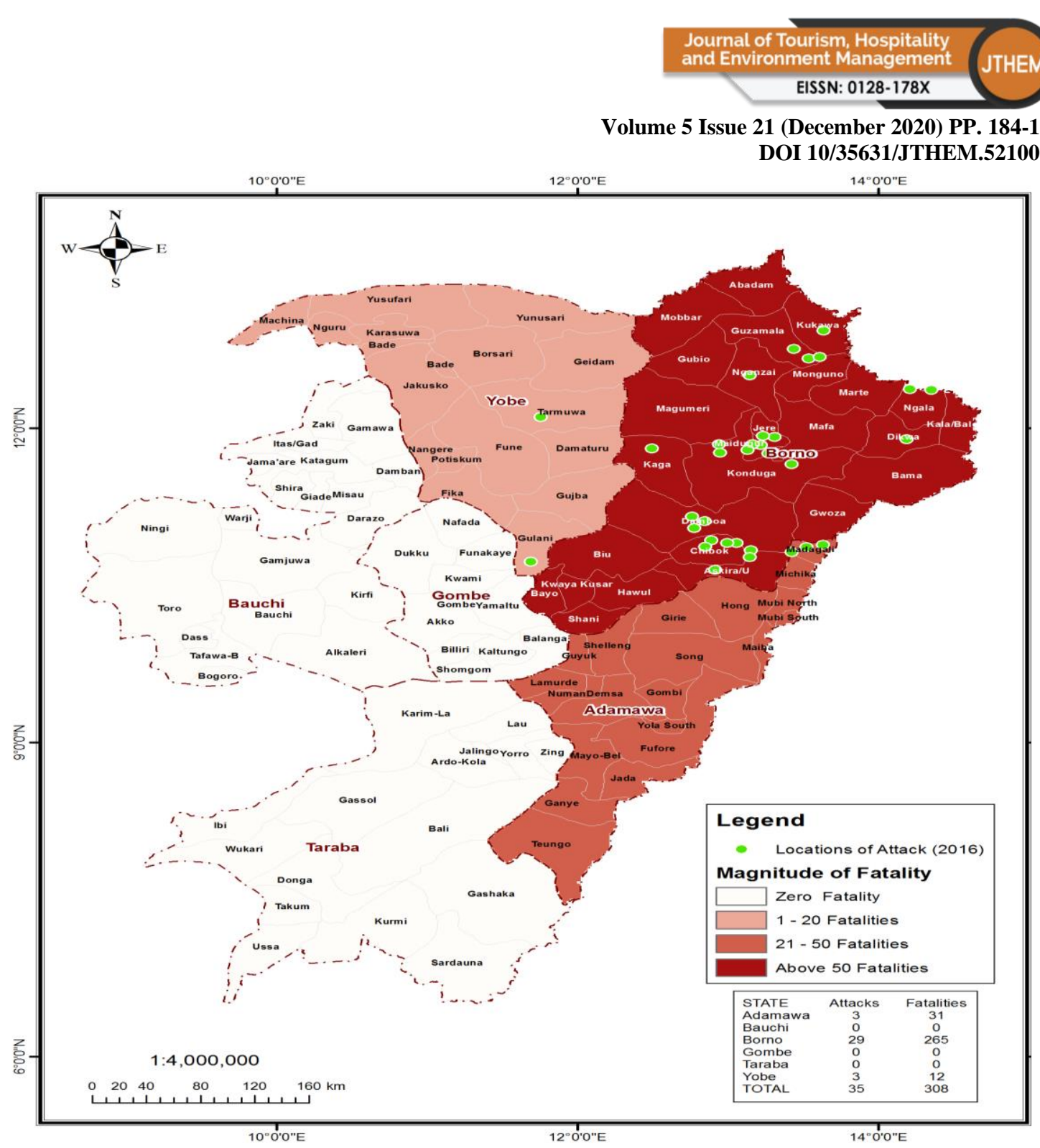

Figure 8: Spatial Distribution of Boko Haram Attacks and Fatalities in2016

Source: Compiled by Author Based on Data from ACLED, 2019

The year 2017 was another year with reduced number of attacks and recorded fatalities from the group, though there was a slight increase from 2016 as revealed in Figure 9. The States directly affected by attacks increased to 4 from previous year. Borno still recorded the highest cases of attacks (81\%) and fatalities (91\%). Adamawa recorded the second highest number of attacks $(8 \%)$ and fatalities $(5 \%)$ for the year, while, Taraba and Yobe had same cases of attacks $(5 \%)$ as well. The other two States of Bauchi and Gombe had no cases of attacks and fatalities. 


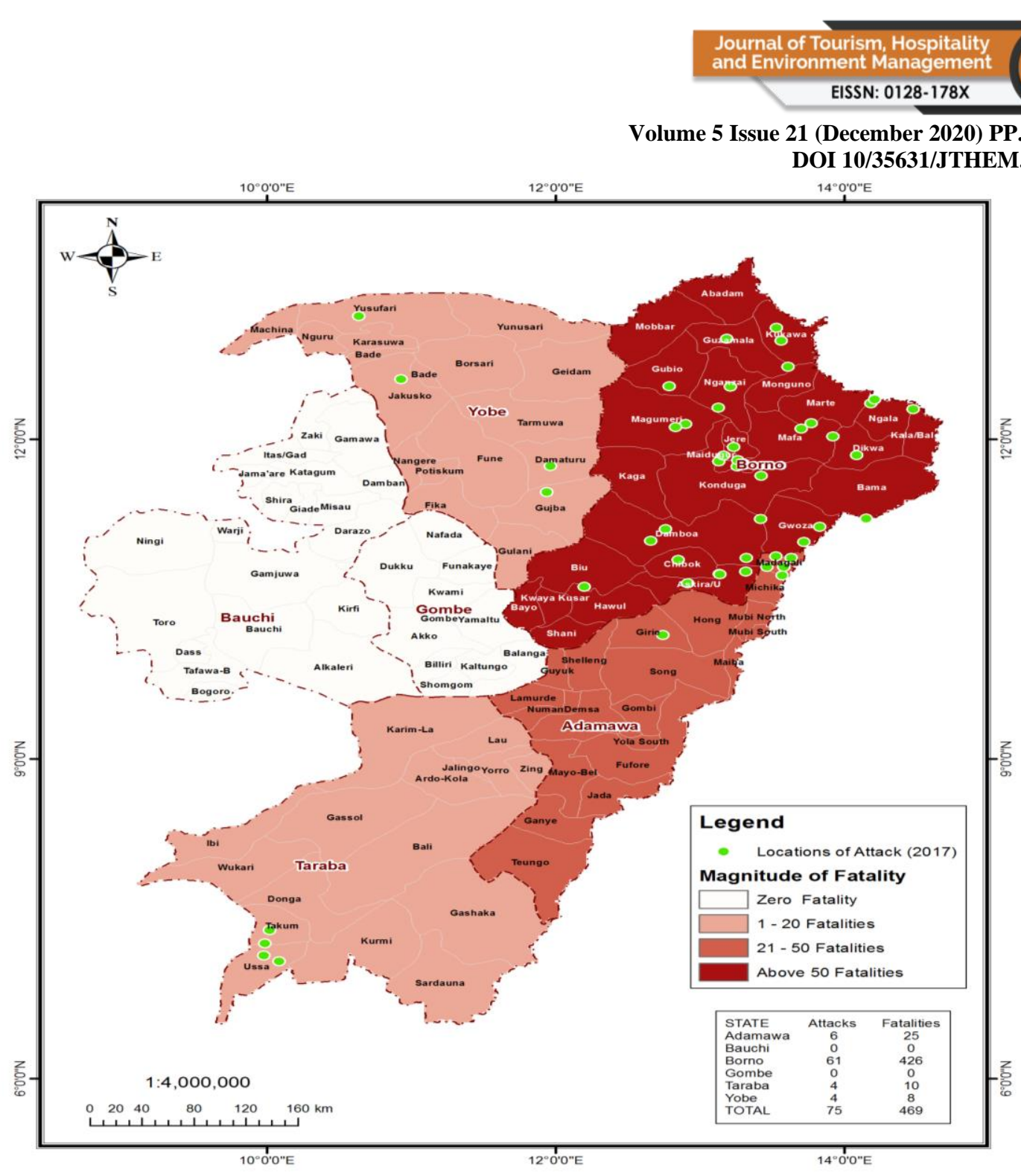

Figure 9: Spatial Distribution of Boko Haram Attacks and Fatalities in 2017 Source: Compiled by Author Based on Data from ACLED, 2019

In 2018 being the last year in review for this study, there was some significant reduction in number of states covered by the group attacks as well as cases of attacks and recorded fatalities as represented in figure 10. Accordingly, Borno still recoded highest number of attacks $(85 \%)$ and fatalities (93\%). Adamawa recorded the second highest cases of attacks (7\%) and fatalities (7\%), while Yobe came in with third highest recorded attacks $(6 \%)$ but with zero record of fatality. The other three states including Bauchi, Gombe and Taraba did not record any attacks or fatalities from the group in 2018 as reviewed. 


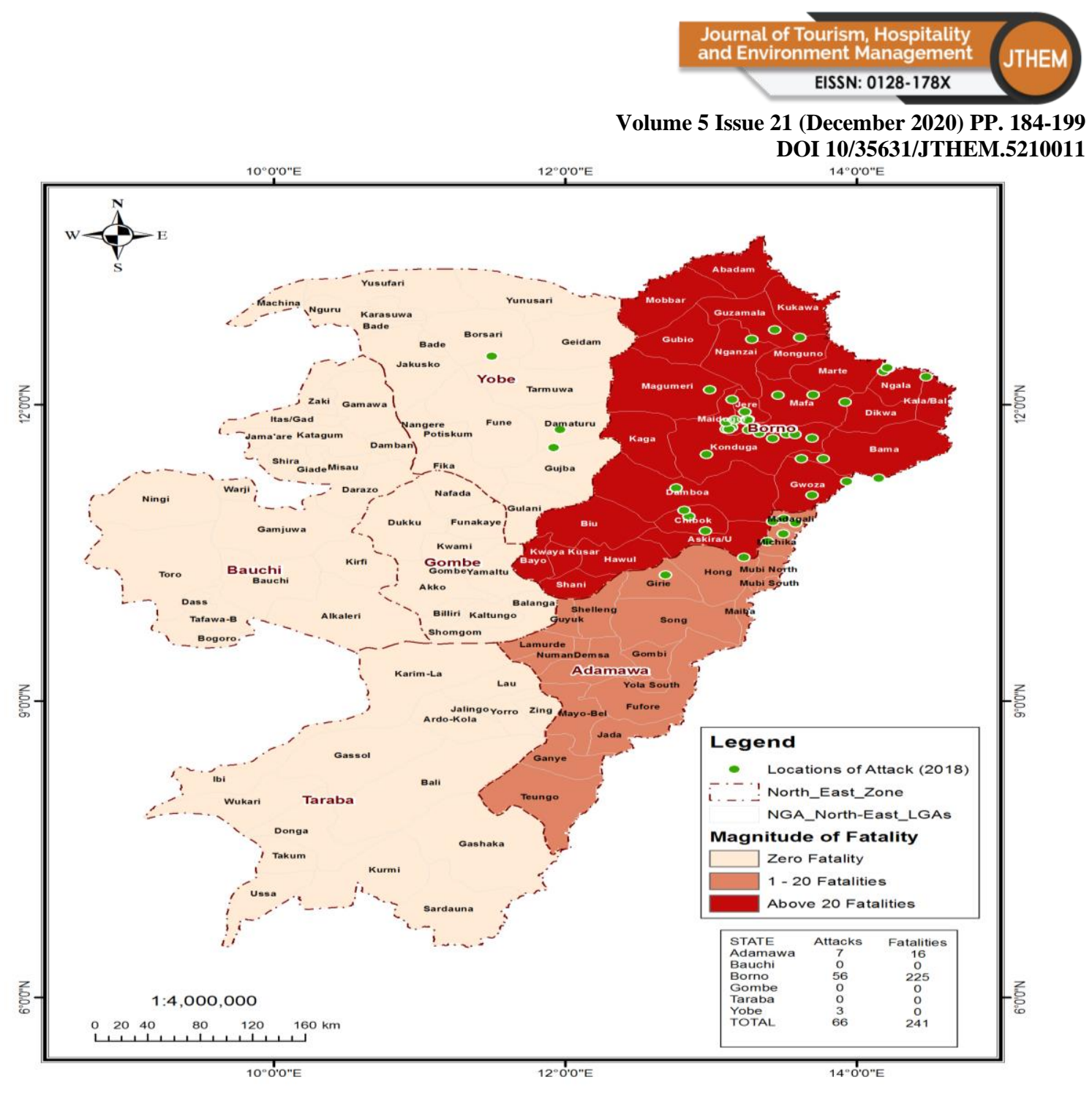

Figure 10: Spatial Distribution of Boko Haram Attacks and Fatalities in 2018 Source: Compiled by Author Based on Data from ACLED, 2019

\section{Spatial Distribution of Hotels Relative to Boko Haram Attacks}

To determine how Boko Haram attacks directly and physically affected hotels in the study area and to determine if significant number o hotels were specifically targeted in the group attacks, coordinates of hotels in the six states of the study area were collected through the use of Global Positioning System (G.P.S). These coordinates were then superimposed on coordinates of Boko Haram attacks to have the map output in figure 11. To also determine proximity of hotels to attacks, (since visitors choice of hotels can be affected by proximity of such hotel to terrorist attacks (citation), a proximity of $1.5 \mathrm{~km}$ of hotels to attacks was determined to see if considerable number of hotels were within this distance.

From the figure, it can be observed that a total number of 660 Boko Haram attacks coordinates were used and a total of 300 hotels coordinates were captured with a total of 2 hotels directly hit or target by the group's attacks in Borno state. It can also be seen that a total number of 15 hotels were located within the proximity distance of $1.5 \mathrm{~km}$ of attacks distributed into 1 hotel each in Adamawa and Borno, 10 hotels in Taraba and 3 hotels in Yobe state. 


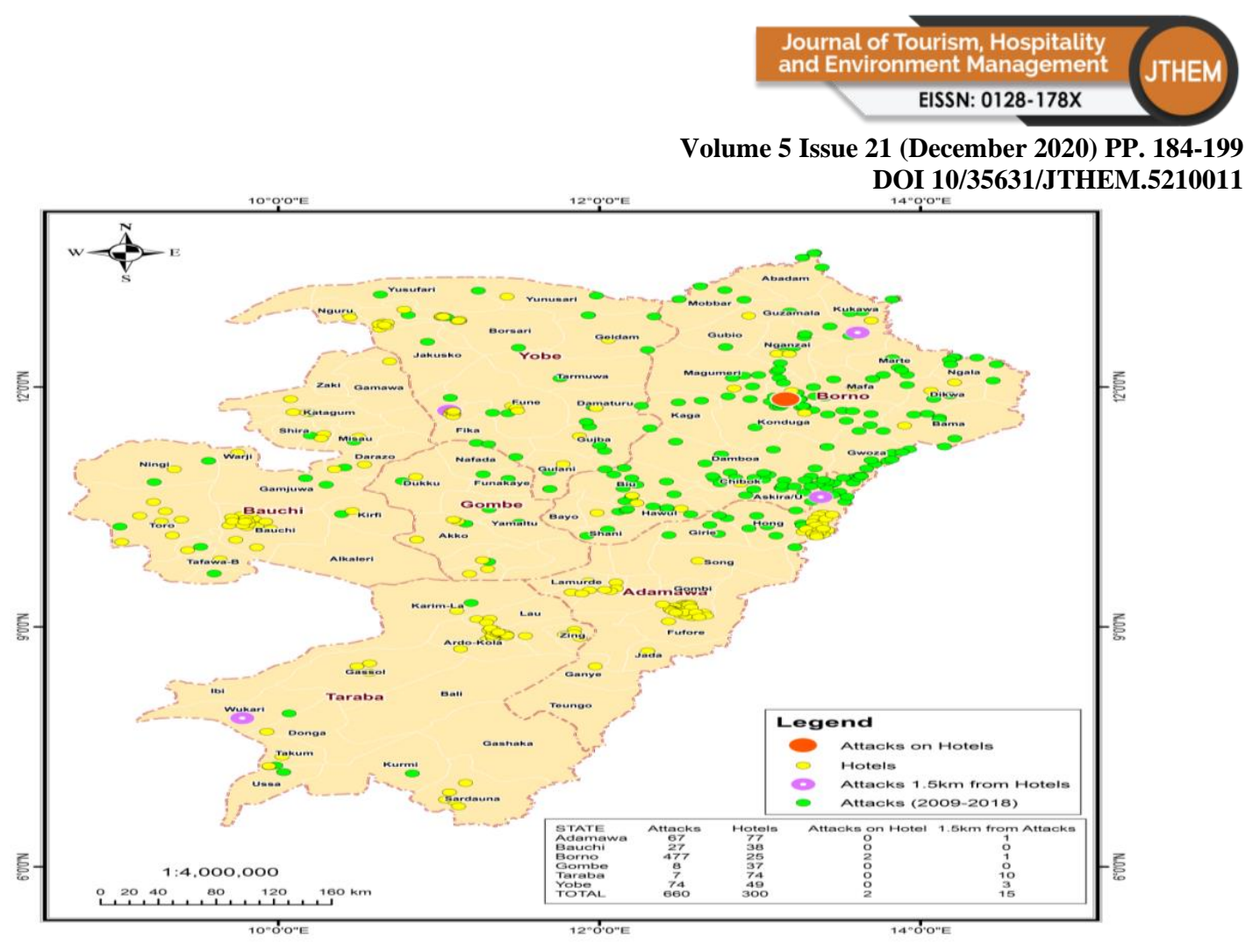

Figure 11: Spatial Distribution Of Hotels Relative To Boko Haram Attacks

Source: Compiled by Author Based on Data from ACLED, 2019

\section{Discussions}

From the data presented, it was found that Boko Haram started most their violent attacks in 2009 and recorded some of the highest number of fatalities in 2013, 2014 and 2015 before dropping again in 2016, 2017 and 2018. These years (2013, 2014 and 2015) recorded some of the highest frequency of attacks too. Borno was the state with the highest frequency of attacks which stood at 521 and a total of 4460 fatalities seconded by Adamawa and Yobe which also recorded significant numbers of attacks and fatalities. Gombe was found to have least number of attacks and fatality with Taraba and Bauchi state also recording some of the smallest number of attacks and fatalities.

It was also found that Borno state is the center point of the group operation. It was also found that the other two states of Adamawa and Yobe which also recorded some of the highest attacks and fatalities were not just neighboring states to Borno but these states also shares very large area of boundary with Borno. This large boundary area could be one of the reasons the group were able to extend their operation to those two states. Though Gombe also neighbors Borno but it shares a smaller boundary area which could be why it has fewer attacks and fatalities too. The study observed that the further the states from Borno, the fewer the number of successful Boko Haram attacks. this could be explained from the point of view of operation coordination, where closer locations were easier to coordinate successful operation while further location could have proof more difficult for the group to coordinate.

The study also found that very few or insignificant number of hotels was directly hit or targeted by Boko Haram attacks. This is an indication that tourist and tourism businesses was not among the primary target by the group unlike other places like worship centers, markets and educational facilities. This is also an indication that tourism businesses doesn't need to be physically targeted by terrorist before being negatively impacted, tourism businesses move 


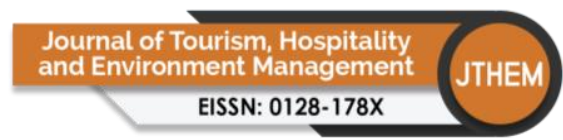

Volume 5 Issue 21 (December 2020) PP. 184-199

DOI 10/35631/JTHEM.5210011

with the people so when there is fear for people to visit a particular place, the tourism businesses in such places also experience decline.

\section{Conclusions}

From the data analysed and findings made in the study, the following conclusions are drawn; That Boko Haram terrorist operation has damaging indirect effects on the socio- economic activities of the study and has directly affected tourism businesses leading to the decline in number of employees, revenues and number of hotels room occupied by visitors.

\section{Recommendations}

This study therefore recommends the following crisis management strategies which are modified to suit the peculiar challenge of the study area:

1. There should be intense promotion of the areas/states that are still safe for visitors to go. For example, apart from Borno, findings from this study revealed that other states in the north east are sparingly hit by Boko Haram. These states can be promoted as safe for tourist.

2. Since the findings from the study shows that tourism businesses were not directly targeted by Boko Haram, there should be a rebranding campaign by concern bodies on how safe the tourism businesses including hotels/motels, resorts, parks, restaurants and many others are and how tourist are safe to go to these places.

3. As part of the recovery plan for the tourism sector of this area, important history and relics like Chibok secondary school, Dapchi secondary school, Sambisa forest and others made popular from the crisis should be redevelop and preserved as tourist site for promotion of tourism after the crisis

4. Generally, government should counter terrorism with development including building social, educational and economic infrastructures in these states and areas that have been liberated from the crisis instead of given excuses of waiting until the whole crisis come to an end before development can commence. The United State (US) did not wait until the Al- Qaeda group were totally defeated before rebuilding the 9/11 attack site. Governments show strength by rebuilding areas captured from insurgency and providing stronger security.

\section{References}

Adebayo, A. A., (2014): Implications of 'Boko Haram' Terrorism on National Development in Nigeria: A Critical Review, Mediterranean Journal of Social Sciences ISSN 20399340(Print) ISSN 2039-2117(Online), Vol 5, No 16

Ajogbeje, K. O; Adeniyi, O. F., (2017): The effect of terrorism on tourism development in Nigeria: A note, First Published February 10, 2017 Research Article https://doi.org/10.1177/1354816617692477

Baker, D. (2014): The Effects of Terrorism on the Travel and Tourism Industry. International Journal of Religious Tourism and Pilgramage, 2(1), 58-67.

Benashvili, G., (2016): The Economic Impact of Terrorism Cost of Terrorism and Counterterrorism, State Economic Policy, Taxation and Development, Vol. 1. First edition, June 2016, London, UK. ISBN: 978-0-9932118-8-1 


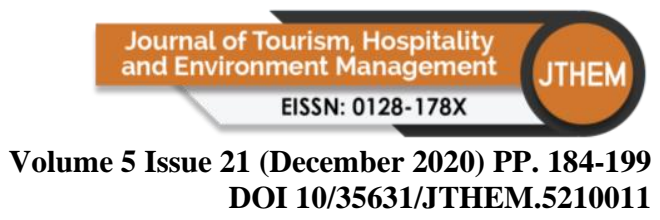

Bosede A; Agyeno, O. (2015): Terrorism in Northern Nigeria: A Threat to Food Security in Maiduguri, Mediterranean Journal of Social Sciences ISSN 2039-9340(Print) ISSN 2039-2117(Online) Vol 6, No 3 S2

Brück T, \& Bengt-Arne, W., (2004): the economic consequences of terror: guest editors' introduction. European Journal of Political Economy, 2004, vol. 20, issue 2, 293-300

Driver, C., (2014). "'See where the fighting is actually taking place': Tourism opportunists offer trips to war zone in UKRAINE for $\$ 50$... which includes a flak jacket and armed guard". Daily Mail. Retrieved 12 September 2014

Economic Intelligent Unit (1994): Country Report for Poland $1^{\text {st }}$ Quarter 1994, London, EIU. https://travel.state.gov/content/travel/en/traveladvisories/traveladvisories/nigeriatravel-advisory.html

Korstanje, M. E., (2018) Terrorism, Tourism and the End of Hospitality in the 'West', retrieved at https://www.palgrave.com/gp/book/9783319522517

Morgan, W., (20 May 2015): "Who Is Ahmed el-Zend? Egypt's New Justice Minister Supports Beheadings and Public Lashings Is Anti-Muslim Brotherhood". International Business Times.

Omede J, \& Andrew, A. O., (2013): Terrorism and Insecurity in Nigeria: Moral, Values and Religious Education as Panaceas, Journal of Education and Practice www.iiste.orgISSN 2222-1735 (Paper) ISSN 2222-288X (Online)Vol.6, No.11, 2015120

Page, S. J., \& Connell, J. (2006). Tourism: A Modern Synthesis. (2th ed.) London: Thomson Learning. Retrieved at http://researchprofiles.herts.ac.uk/portal/en/publications/tourism-a-modern-synthesis (af4a09fd-7749-47e5-8f9f-5060ba486d86)/export.html

Pizam, A. \& Fleischer, A. (2002): Severity vs. Frequency of Acts of Terrorism: Which Has A Larger Impact on Tourism Demand? Journal of Travel Research, 40(3): 337-339.

Seddighi, H. R.,\& Theocharous, A. L. \& Nuttall, M. W., (2001): Political Instability and Tourism: Journal of Travel Research, 48(3): 437-439.

Shah, M. H., \& M. Faiz (2015): Terrorism and Foreign Direct Investment: An Empirical Analysis of SAARC Countries, City University Research Journal, 219-233

Sönmez, S. \& A.R. Graefe (1998): Influence of Terrorism Risk on Foreign Tourism Decisions. Volume 25, Issue 1, January 1998, Pages 112-144. Annals of Tourism Research

Sonmez, S. F. \& Graefe, A. R., (1998a): Infuence ofterrorism risk on foreign tourism decisions. Annals of Tourism Research, 25 (1),112-144.

UNWTO Tourism Highlights, (2005): Edition Published: 2005 eISBN: 978-92-844-1190-0

UNWTO Tourism Highlights, (2015): Edition Publ 